\title{
Between disputatio and Polemics: Dialectics as Production of Knowledge in the Middle Ages
}

\author{
Bénédicte Sère*
}

At the basis of the medieval production of knowledge, dialectics seems to be one of the primary keys of thought. Medieval thinkers were trained to express and to represent the world according to the disputatio, which is a question of research and a form of academic exercise. They were trained to discuss and to challenge. We can distinguish two kinds of dialectics: an irenic one, ritualized dialectics, as Habermas has shown on the one hand, and a more polemical dialectics, as theorized by Pierre Bourdieu, on the other. Our main aim is to establish that those dialectical techniques of disputatio or polemical treatises are tools to produce doctrines and thought. On the one hand, we analyze the typical scholarly disputationes produced in commentaries on Aristotle's Ethics, within the Western university sphere. On the other, we focus on political and ecclesiological treatises in the time of the Great Schism, as a case study to understand the difference between irenic disputatio and polemical exchanges. The final thoughts in this article aim at contextualizing the self-awareness of the specialists of scholasticism within the saturation of polemics and the broadening of their audience through reaching a non-academic audience. The example of the well-known university theologian Jean Gerson is particularly relevant in the attempt to move beyond the world of the university.

Keywords: scholasticism; commentaries; Aristotle; debates; dialectics; disputatio; polemics; production of knowledge; Great Schism; Jean Gerson

\section{Introduction}

In the context of the medieval West, intense intellectual production was first concentrated in the monastic world (from the Carolingian period until the eleventh century), then knowledge was developed in parallel in schools. In the twelfth century, it was mostly found in schools and then in universities - that is, the legal grouping of schools - from the thirteenth century. In the twelfth century, the master attracted students and founded his school. The example of Anselm of Laon is famous, and that of Peter Abelard is also well known thanks to his autobiography, the Historia calamitatum. Unlike Anselm of Laon, Abelard forged the dialectical method for his teaching, a position of refutation of the authorities, rather than a simple juxtaposition of sentences and ready-made authoritative formulas. Indeed, as the basis of the medieval production of knowledge, dialectics seemed to be one of the primary keys of thought. Medieval thinkers were trained to express and to represent the world according to the disputatio, which is a question of research and a form of academic exercise. They were trained to discuss and to

\footnotetext{
* Correspondence details: Bénédicte Sère, University of Paris Nanterre, 201 avenue de la République, 92000 Nanterre Cedex, France; email: Benedicte.sere@sfr.fr.
} 
challenge. Inspired by two icons of post-structuralist thought, we can distinguish two kinds of dialectics: an irenic one, ritualized dialectics, as Habermas has shown on the one hand, and a more polemical dialectics, as theorized by Pierre Bourdieu, on the other. ${ }^{1}$

To oppose Habermas and Bourdieu is to oppose the paradigm of dialogism and the paradigm of conflict: the ethos of communicational action confronts the sociology of conflict and of violence. Jürgen Habermas proposed, concerning the public sphere, an ethic of the discussion of the theory of non-violent communication (zwanglos), which has inherited the disputationes' habits of producing knowledge during antiquity and the Middle Ages. ${ }^{2}$ According to Pierre Bourdieu, the progress of scientific knowledge has to be defined as a Kampfplatz, that is to say, a vast space of symbolic confrontation of powers. It deals with the sociology of symbolic power relations: "S’il y a une vérité, c'est que la vérité est un enjeu de luttes «. ${ }^{3}$ Intellectual violence, which is close to symbolic violence as defined by P. Bourdieu, could also be envisaged as a violence in terms of relations to the truth, i.e., to interpretation: it is about imposing its vision of the world and then monopolizing a form of power through expertise, competence, and language. There are close links between debates, violence, and the public sphere. In this paper, our main aim is to establish that those dialectical techniques of disputatio or polemical treatises are tools for producing doctrines and thought.

\section{Ritualized and Irenic Dialectics: The disputatio}

What is the disputatio?

All the works by Olga Weijers have studied disputatio: O. Weijers might be the only scholar to have synthesized the theme in a couple of handbooks and not only in proposed case studies. For the sake of clarity and by way of introductory remarks, we can summarize some of the main topics of her work, bearing in mind other famous scholars on disputationes and other approaches. ${ }^{4}$ Disputatio - which we could translate as »dispute«, »argument«, or »discussion " - has to be understood in the more technical sense of the word. ${ }^{5}$ It is well known that in the Middle Ages disputatio was a teaching and research method, as well as an exam technique and an omnipresent form of exercise in the intellectual and university habits of medieval thinkers. Linked to the Aristotelian definition of the dialectic, the disputatio was performed in the form of an oral debate between two or several interlocutors and was to be held in front of an audience. One opponens presented objections to the proposed thesis, then a respondens was supposed to offer some counter-arguments to the first objections, in order to produce a real debate of arguments in this implementation of the Sic et non method.

1 See Bourdieu, Champs scientifique; id., Sciences de la science; id., Méditations pascaliennes, 5: „Violence symbolique et luttes politiques", for instance 246,248 , or 267-268.

2 Habermas, Strukturwandel der Öffenlichkeit; id., Theorie des kommunikativen Handelns.

3 Bourdieu, Leçon sur la leçon, 25.

4 For instance, a recent issue of the journal Early Medieval Europe, entirely devoted to disputation in Carolingian Europe, is edited by Mayke de Jong and Irene Van Renswoude; see "Carolingian Cultures of Dialogue, Debate and Dispute«, Special issue of Early Medieval Europe, 25/1 (2017). For the other periods and other scholars, see also Bazàn, Quaestio disputata, Bazàn et al., Questions disputées; Maierù, Academic exercises; more recently, see Gindhart and Hundert, Disputatio 1200-1800; Waquet, Longue vie; Périgot, Dialectique et littérature; id., Antécédences; Angelelli, Technics of disputation; Libera and Rosier, Argumentation in the Middle Ages; König-Pralong, Avènement de l'aristotélisme, 24-32.

5 About the disputatio, see Weijers, Faculté des arts de Paris; id., Facultés des arts au Moyen Âge; id., Quelques observations, 35-48; id., Joute dialectique, 508-518. See also Bazàn et al., Questions disputées. 
Once all arguments were exhausted, the master ended the discussion and determined (from the Latin determinare) the result of the debate in an argued solution called the "determinatio «. The essence of the disputatio was, then, that of a dialogical, even agonistic, exercise within specific frameworks with very codified and academic rituals. The dialectic, which until then had been only a simple instrument, became a real tool of analysis with Abelard. The Sic et non is constructed as a collection of patristic authorities. Each of the authorities was used and confronted in order to nourish a dialectical approach, "according to the pro and to the contra «, on the basis of the questions asked of the Bible: Abelard exposed the different patristic points of view and the way of erasing contradictions, which might find common ground or might reach an agreement beyond contradictions and discrepancies. With the Sic et non, Abelard as "the great chevalier of the dialectic (Paul Vignaux) drew more from discussion itself than from the text of reference. ${ }^{6}$ In his dialectical practice, Abelard was able to deconstruct his adversaries' authority (Guillaume of Champeaux, Anselm of Laon) by basing himself solely on the use of reason. He built the dialectical discussion derived from contradiction and discrepancy (dissonantia) as the best method to reach the truth. There was a visible didactic and heuristic dimension in the gathering of contradictory texts to write the Sic et non. The Abelardian dialectic was more than a method. It was a mental attitude, an art of argued discussion, an art of convincing and confusing the adversary in the debate. According to Alain de Libera, "all the spirit of the late Middle Ages philosophy was influenced by Abelard «.?

Distinct from dialectical disputatio, the scholastic disputatio was much more a research method to discover the truth of a problem: we can speak about a disputatio inquisitivum. The scholastic disputatio was developed from the quaestio during the twelfth century. It was structured in three stages: after the formulation of the issue, preliminary arguments were exposed, which were themselves divided into arguments pro - in favor of the thesis - and arguments contra - against the thesis. ${ }^{8}$ Then the master determined the determinatio by exposing the solutio (solution) of the issue. Finally, the disputatio ended with the refutation of the preliminary arguments. This tripartite structure depended more on a ritualized process than on an official debate of ideas. It seemed to be more of a research method than an argumentative duel. This practiced scholastic disputatio was, then, definitely built on a collective process of thought. First and foremost, it dealt with the sharing of arguments, which was sort of a collective search for the truth. Thomas Aquinas says that we should esteem those who, after investigation of the problem, come to a contrary opinion, even if we choose to follow arguments that seem to us to be nearer to the truth. ${ }^{9}$ The scholastic disputatio involved

6 For the expression, see Vignaux, Philosophie au Moyen Âge, 126.

7 De Libera, Pierre Abélard, 1099.

8 It is important to specify that the arguments ad oppositum (contra, contrarium) were not simply arguments against the answer first proposed, but arguments in favor of the alternative answer. Both answers could then be attacked by arguments from the opponents. At the end of the disputation, those preliminary arguments given for the answer finally rejected were rebutted by the master.

9 Thomas Aquinas, Commentary on Aristotle's Metaphysicis 7, ix: »But, because in choosing opinions or repudiating them a man must not be guided by love or dislike of the one who introduces the opinion, but more by the certainty of the truth, therefore he (Aristotle) says that we should love both, that means those whose opinion we follow and those whose opinion we repudiate; for both have applied themselves (studuerunt) to the inquiry of the truth and they have helped us in this. But still, we should be spersuaded by the most certain<, that means we should follow the opinion of those who reached the truth more certainly." 
at least three people, as we have said: the opponens, the respondens, and the master. There were disputationes in scolis, which were private disputes, and disputationes solemnis or disputationes magistrorum, some kind of public dispute in front of all the masters and the students of the faculty, in general on afternoons, once a week, all year long. Attendance was obligatory for all students for two years. The determinatio was not a simple juxtaposition of contrary arguments: it was rather the subsuming of all debated views into a new position. The disputatio was the sign of a constitutive mechanism of thought, which was built and produced in the form of a ritualized dialogue, but a living one.

The disputation was present in all its forms in university life and intellectual literacy: during monotonous lecture days, special events, daily exercises, oral meetings between master and students, entertainment exercises, commentaries, and treatises. Moreover, the disputation had a function in the task of examinations. During normal participation in the private disputations of their masters, and also in public disputations, the final examinations and ceremonies also consisted in large part of disputations, especially during "inception " - the ceremony by which the candidate became a master and was accepted into the corporation of the masters of his university - and the preliminary vesperies, during which he functioned for the last time as the respondent in a solemn disputation. ${ }^{10}$ For instance, the baccalaureate involved the "determination " (determinatio) as the candidates were required to "determine" disputations during Lent. After this, the candidate obtained the »license to determine" (licentia determinandi) and was permitted to engage in the disputations. The examination would somehow be a test of practical competence rather than an evaluation of accumulated knowledge. What Olga Weijers calls "the omnipresent disputation« is not a euphemism:

In the faculty of arts students learned to handle the techniques of disputation and discovered how this method could be used for didactical, doctrinal and polemical purposes. When they reached the higher faculties, they were therefore well trained in it; the disputation remained one of the most important methods in theology, law and medicine. (...) The sources are numerous and very rich. There are prescriptions about the disputation in the statutes of the universities, written reports or oral disputations, redactions made by the masters after discussion sessions, collections of disputed questions, and directly composed treatises in the form of disputations. The second point to mention is the general belief of the medieval masters that the disputation was a tool for discovering the truth, or at least of understanding and teaching the truth as they saw it. This was the basic function of the method, as numerous sources make clear (...)

It is clear that the disputation was ubiquitous in university life. From the beginning of the thirteenth century onwards no master or student could escape the handling of this tool for teaching, research and examination. It became so omnipresent that in later times, in the eyes of the Renaissance humanists, the scholastic method was reduced to trivial quarreling about details. This bad reputation lingered on for centuries, but at the same time the disputation profoundly changed Western culture's approach to reasoning. ${ }^{11}$

10 Ibid., ch. 9.

11 Weijers, Scholar's Paradise Teaching, 121, 135. 


\section{Ritualization and Codification of the disputatio Method}

Because most of the quaestiones were founded on an authoritative text (the Bible, Aristotle, Sentences, Corpus Juris civilis, or Decretum), the disputatio is the framework of all commentaries. A divisio textus introduced the text in order to explain it, and a series of quaestiones followed in order to cover the whole text that had to be commented on. We speak about commentarius made up of quaestiones. Even if their purpose was to comment on the literal sense of the auctoritas, some commentaries on the authoritative text were very close to real treatises. From the fourteenth century onwards, many treatises, indeed, written in the form of disputed questions, without any indication that there had been a real disputation preceding the redaction or that they were instigated by commentaries and not explicitly treatises. No trace of oral discussion can be found because those treatises seem to have been conceived in the form of quaestiones. In the course of the writing of the treatise, the procedure of disputation was used as a form of analysis, to discuss serious problems or controversial topics: the basic scheme, the dialectical tools, the quotation of other opinions. One of the most famous examples might be the Summa theologiae of Thomas Aquinas: this theological work consisted of extensive collections of disputed questions, treated in the basic format, and the individual questions were here called articuli, "articles", or parts of a complicated question. These "articles" were a kind of basic working unit for the discussion. Every "article" is constructed like a disputed question. The genre of quaestiones disputatae could also be linked to some oral teaching courses, but one must keep in mind the discrepancy between the oral moment and the final written product. Because this point is very well studied and very well known, we can leave it aside and simply quote some recent works dealing with this topic. ${ }^{12}$

But these quaestiones were artfully constructed. Alain of Libera spoke about the CQR: "complexe-questions-réponses"/»questions and answers complex", for which one had to analyze in detail the construction to understand where the author's thought was hidden. Indeed, the solutio was not the reflection of the author's thought but rather the canonical position to adopt. For instance, the author's position was less in the canonical solutio but more in the subtle disposition of the preliminary arguments. It is indeed essential to reconstitute the architecture of a CQR. It is necessary to relocate the issue, the quaestio, in its exegetical traditions, which are the basic frames of each commentary.

What do we mean when we say that a quaestio is highly codified, or more generally, that the genre of the commentaries is skillfully structured? As this is not the place to expose all the history of disputatio in the last 300 years, and as we have already dealt with this more extensively elsewhere, ${ }^{13}$ let us focus on the fifteenth century and take, from many, one demonstrative example. The example found in Johannes Versor's commentaries demonstrates the matter thoroughly. Johannes Versor (1410-1482) was a master of arts at the University of Paris in 1435 and the rector in the same faculty in 1458. He became a master of theology at that time. He was a notorious and brilliant commentator of Aristotle's works in the 1440 s

Mandonnet, Saint Thomas d'Aquin; Chenu, Introduction à l'étude; Marmursztejn, Autorité des maîtres, 24-32; Sère, Thomas d'Aquin.

13 Sère, Penser l'amitié. For the antecedents of the disputatio and the twelfth-century authors, see Sère, Disputatio dans l'université médiévale. 
and 1450 s. ${ }^{14}$ Among many works of Aristotle, the commentary on Nicomachean Ethics was the most appropriate for moral and political considerations. Into the interpretative chains of commentaries on Aristotle's Ethics, Versor's commentary was inserted at a particular point at the crossroad of Thomas Aquinas's filiation and of Buridan's inheritance, which were two opposite lines of interpretation, as shown in the diagram: ${ }^{15}$

14 Johannes Versor, Questiones super veterem artem: avant 1442; Questiones super totam novam logicam: avant 1442; Questiones super libros Metaphysicae: avant 1443; Questiones super libros Physicorum: avant 1446; Questiones super libros de Caelo et mundo: avant 1443; Questiones super libros de Generatione et corruptione: avant 1444; Questiones super libros Meteorum: avant 1450 ou 1451; Questiones super libros de Anima: avant 1443; Questiones super libros parvorum naturalium: avant 1443; Questiones super libros Ethicorum: avant 1446; Liber Yconomicorum Aristotelis cum commento magistri Johannis Versor: 1462; Questiones super libros Politicorum: 1457; Super logicam Petri Hispani. (1457?); Commentum super de Ente et Essentia de Thomas de Aquino: avant 1445; Super Donato (?).

15 To go further, see Sère, Penser l'amitié, 64, and c. 1. Here is not the place to comment on this Stemma influenciae, quoted from our doctoral work and published in 2007. Let us say that the stemma establishes a network of scholars, a sort of culture of transmission and reuses. Two main lines emerge in these exegetic traditions: the one from the Mendicant writers, initiated by Albert the Great and extended by Aquinas. It contains other mendicant authors, not necessarily belonging to the Preachers, such as Henry of Frimar (OESA), and secular authors, such as Gilles d'Orléans, Petrus de Corveheda, Walter Burley, Albert of Saxony, Guillelmus Becchius, or Donato Acciaiuoli. The second exegetic tradition begins with Guiral Ot, the well-known Franciscan author, at the beginning of the fourteenth century. It generates Buridan's commentary and those of the Buridanian authors (Nicolas of Amsterdam, Paulus of Worczyn). At the crossroads stands Nicole Oresme, Charles V's famous translator. 
Stemma influenciae of the interpretation traditions on the Nicomachean Ethics thirteenth-fifteenth centuries

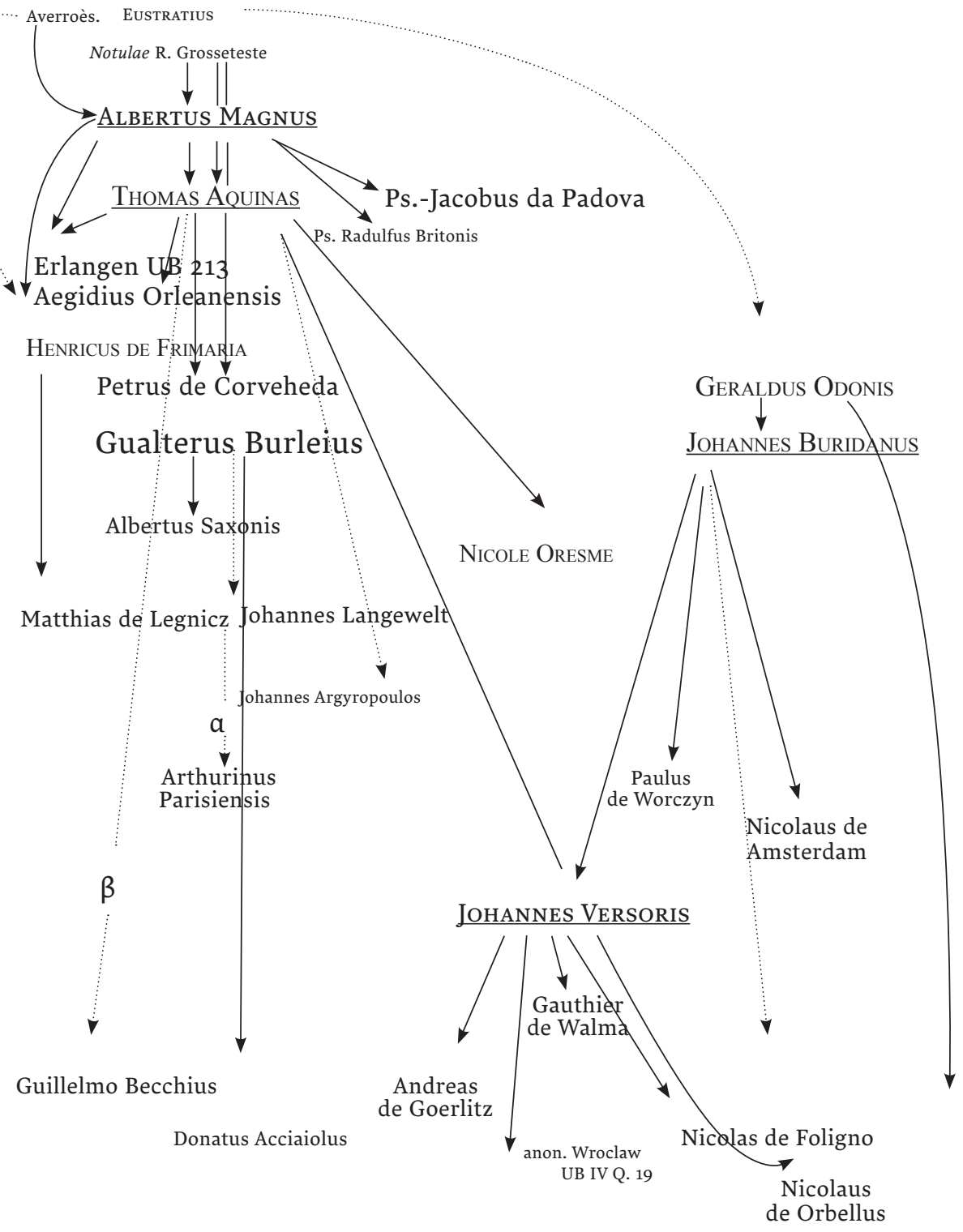

Bernardus de Nyssa 
Johannes Versor's commentary on the Ethics was built upon alternating between these (both authoritative) quotations in order to create an illusion of doctrinal concordance. ${ }^{16}$ His commentary was indeed an exceptional product of the art of commentary. Versor was particularly talented at manipulating the CQR (questions and answers complex) while he composed and compiled his commentaries. In his commentary on the Ethics, each quaestio was composed with the juxtaposition of two auctoritates - Thomas Aquinas on the one hand, and Johannes Buridanus on the other. ${ }^{17}$ Their dialogue, hidden at first sight, but unmasked after analysis, is particularly relevant.

Let us take one specific example, the quaestio: Utrum amicicia sit virtus. ${ }^{18}$ At the very beginning of Book VIII, Aristotle wondered if friendship was a virtue (virtus/exis) or just something close to a virtue. The answer, however, was not very clear. He said: »Friendship is indeed a kind of virtue or something with virtue ", "Amicicia est enim virtus quaedam vel cum virtute «. ${ }^{19}$ To address this question, Versor had access, in the fifteenth century, to two significant positions elaborated in the course of the preceding generations: the Thomist position, according to which friendship was an effect of virtue, and the Buridanian position, in which friendship was itself a virtue. ${ }^{20}$ The two lines of argument leading to those positions were both very solid and convincing, and nothing justified choosing one or the other because Aristotle's words themselves, in the text, were very ambiguous. The first impression, then, is that Versor's commentary dealt with the two in a balanced manner; that his response was one that discussed the two positions with apparent good faith and rigor. Versor used Aquinas for all solutiones and employed Buridan for preliminary arguments, their refutations, and all the dubia (doubts). It would seem that Aquinas and Buridan were allowed the same speaking time and that they were reconciled in one quaestio, as a reconciliation between the via antiqua and the via moderna, between Thomism and Buridanism. We could speak of concordism or doctrinal irenicism. This was how things appeared at first sight. However, after having looked more closely, it was possible to discover some very skillfully constructed CQR. Indeed, the juxtaposition of both auctoritates, Aquinas and Buridan, was not so much a level presentation of two positions as it was a resolute destruction of one thesis in favor of the other, that is to say, the destruction of Buridanism in favor of Thomism. Let us look at the three first arguments of the oppositum in the Buridanian quaestio. Versor chose to place in his preliminary arguments those that Buridan chose to defend. That is to say, Versor chose to attack arguments that Buridan defended:

16 About Johannes Versor, Erich Meuthen spoke of a "Verschulungstendenz«, see Meuthen, Kölner Universitätsgeschichte, 185: "Besondere Verbreitung fanden die entsprechenden Kommentare des Johannes Versor, eines der für die Verschulungstendenz insgesamt kennzeichnenden Gelehrten des ausgehenden Mittelalters."

17 Thomas Aquinas, Sententia libri Ethicorum; Johannes Buridanus, Quaestiones super decem libros Ethicorum.

18 Johannes Versor, Quaestiones super libros ethicorum Aristotelis, fol. 79va-80va.

191155 a 3. Aristoteles Latinus, Ethica Nicomachea 50.8, ch. 1, 298.

20 Ibid., fol. 8ora-rb: "Conclusio prima. Amicitia secundo modo accepta est virtus moralis«, and also: "Conclusio secunda. Amicicia primo et tercio modo accepta non est virtus«. 


\begin{tabular}{|c|c|}
\hline $\begin{array}{l}\text { Johannes Buridanus, } \\
\text { Quaestiones, fol. 169ra. }\end{array}$ & $\begin{array}{l}\text { Johannes Versor, } \\
\text { Quaestiones, fol. 79va. }\end{array}$ \\
\hline $\begin{array}{l}\text { ARGUITUR quod non, per hoc quod Aristote- } \\
\text { les determinavit de ea seorsum postquam iam } \\
\text { dimisit tractare de virtutibus tam moralibus } \\
\text { quam intellectualibus. } \\
\text { ITEM, secundo Magnorum moralium Aristote- } \\
\text { lis, antequam tractaret de amicitia, dixit se iam } \\
\text { de singulis virtutibus determinasse. } \\
\text { ITEM Tullius in fine libri sui de amicitia videtur } \\
\text { amicitiam distinguere contra virtutem dicens: } \\
\text { "Vos autem hortor ut ita virtutem locetis, sine } \\
\text { qua amicitia esse non potest, ut, ea, scilicet } \\
\text { virtute, excepta, nihil amicitia prestabilius pu- } \\
\text { tetis« [De amicitia, 104]. } \\
\text { ITEM alibi in eodem libro dicit: "Una est enim } \\
\text { amicitia in rebus humanis de cuius virtute [Cic. } \\
\text { utilitate] omnes uno ore consentiunt. Quam- } \\
\text { quam a multis ipsa virtus contemnitur et ven- } \\
\text { dicatio quedam atque ostentatio esse dicitur» } \\
\text { [De amicitia, 86]. } \\
\text { ITEM effectus virtutis non est ipsa virtus. Amicitia } \\
\text { autem est effectus virtutis dicente Tullio: "Qui } \\
\text { autem in virtute summum bonum ponunt, preclare } \\
\text { illi quidem, sed hec ipsa virtus amicitiam gignit et } \\
\text { continet« [De amicitia, 2o]. } \\
\text { (1) OPPOSITUM arguitur auctoritate Senece } \\
\text { epistola } \text { Immeritor ad Lucilium quia amicitiam } \\
\text { vocat virtutem dicens quod: "Sapiens et si con- } \\
\text { tentus est se, tamen habere vult amicum ut se } \\
\text { exerceat ne tam magna virtus jaceat«. } \\
\text { Etiam Tullius in libro suo De amicitia prefert } \\
\text { eam omnibus bonis humanis dicens: "Ego vos } \\
\text { tantum hortari possum ut amicitiam omnibus } \\
\text { rebus humanis anteponatis". Nullus habitus } \\
\text { qui non sit virtus est sic omnibus humanis bo- } \\
\text { nis anteponendus. } \\
\text { (2) ITEM [...] } \\
\text { (3) ITEM nullus habitus videtur magis neces- } \\
\text { sarius in civili communicatione quam virtus, } \\
\text { in qua tamen Aristoteles dicit magis opus esse } \\
\text { amicitia quam justicia. } \\
\text { Videtur michi quod ad concordandum diversas } \\
\text { oppiniones doctorum solemnium et ad salvand- } \\
\text { um rationes eorum que, ut puto, necessario } \\
\text { concludunt, distinguendum est de amicicia et } \\
\text { consimiliter de dilectione et amore. Sepe enim } \\
\text { istis tribus nominibus utimur promiscue. [...] }\end{array}$ & $\begin{array}{l}\text { [ARGUITUR] TERCIO sic: nullus habi- } \\
\text { tus est magis neccessarius et opus com- } \\
\text { muniter civili quam amicicia, quia ipsa } \\
\text { est magis opus quam justicia que est } \\
\text { quaedam virtus, ergo et amicicia. } \\
\text { Et hoc idem videntur sentire Eustrati- } \\
\text { us, Seneca, Tullius et Sanctus Thomas, } \\
\text { qui dicit in principio presentis capituli } \\
\text { quod »Sicut in aliis virtutibus quidam } \\
\text { dicuntur boni secundum habitum et qui- } \\
\text { dam secundum actum, ita etiam contin- } \\
\text { git in amicicia«. Et Eustratius dicit quod } \\
\text { amicicia est una virtutum. } \\
\text { (Et Tullius in libro De Amicicia prefert } \\
\text { eam omnibus bonis humanis. Sed nul- } \\
\text { lus habitus (qui non est virtus) prefertur } \\
\text { omnibus bonis humanis, igitur etc. } \\
\text { (Similiter Seneca in epistola Ad Luci- } \\
\text { lium vocat amiciciam virtutem dicens } \\
\text { quod: »Sapiens vult exercere amiciciam } \\
\text { ne tanta virtus pereat«. } \\
\text { IN OPPOSITUM arguitur quia Philo- } \\
\text { sophus in principio octavi dicit quod } \\
\text { "Amicicia aut est virtus vel cum virtu- } \\
\text { te«. Ibi communiter dicunt expositores } \\
\text { quod amicicia non est virtus sed conse- } \\
\text { quitur virtutes. }\end{array}$ \\
\hline
\end{tabular}


Versor, in the fifteenth century, reused Buridan's material with all its quotations and arguments, but he returned to it for the sake of the thesis he defended. This was a subtle manipulation - non-violent, but effective. Aquinas's thesis was defended as shown in the In oppositum: "Ibi communiter dicunt expositores quod AAmicicia non est virtus sed consequitur virtutes. " Versor never mentioned Aquinas. He only said: Expositores, that is to say, "the Commentators", generally speaking, which is a way to avoid quoting anyone explicitly. Versor dipped into Buridan's best counter-arguments, the ones Buridan attacked. He then used all the auctoritates that Buridan found, such as Cicero, Seneca, or Eustratius. He overturned them for the benefit of his thesis.

When Versor was saying, in a neutral tone, Respondet secundum Buridanum, carefulness is required: indeed, he did not say Buridan respondet, but he said Respondet secundum Buridanum, that is to say, Buridan did not answer - due to the fact that he did not defend the same position - but Versor used Buridan's preliminary arguments to defend his position. This was honest, but it created a visual effect. Between Aquinas and Buridan, it seemed that there had been a pacific coexistence. The presentation did not show any dissension. However, Versor was still a convinced Thomist. Like a maestro, he was able to interlace two auctoritates, presenting Buridan's arguments in order to teach Aquinas's arguments better. It was a new technique of refutation, not seen in the first scholastic times: a refutation by inversion. That is to say, he refuted Buridan by Buridan. There was - despite the pious wishes - no concordism. For the historian, understanding the mechanism of such a doctrinal position is a question of detail.

By encircling more closely the specificity of the commentary and the technique of CQR for each quaestio within the medieval configuration of knowledge, it appears that the commentary made up of questions defined itself above all in a specific relationship with the auctoritas to which it referred. What was the medieval peculiarity of this relationship at the end of the Middle Ages? Even though it is something of a truism, to write a commentary in the Middle Ages was always to write it on an auctoritas. Now, by studying the structural mechanisms of the commentary on the Ethics, it turns out that it is possible to formulate a definition of the auctoritas - in this particular case, the Aristotelian auctoritas. For the commentaries, Aristotle does not become confused with the truth. It is evident that the auctoritas is not the truth. What is more, it does not give the truth. The auctoritas, when it inspires a commentary, operates instead by making one think, provoking thoughts. To say that authority instigates thought is to include that it possesses in itself a power of begetting thought. Authority makes possible the production of speech about itself and beyond itself. It opens up the possibility of speeches on something other than itself. The auctoritas operates as a condition of the possibility of thought. "They open the space for something else than themselves and which nevertheless belongs to them to establish «. ${ }^{21}$ That is why auctoritas does not need in itself to be the truth and we have many cases of examples when there is a "useful wrongness" in the auctoritas which is to be commented in order to seek the truth.

21 Foucault, Qu'est-ce qu'un auteur?, 833. With the example of Freud's Traumdeutung or Marx's Manifeste, Michel Foucault stipulates what is a »fondateur de discursivité« or »instaurateur de discursivité«, 832-833: "Ces auteurs ont ceci de particulier qu'ils ne sont pas seulement les auteurs de leurs œuvres, de leurs livres. Ils ont produit quelque chose de plus: la possibilité et la règle de formation d'autres textes. [...] Ils ont établi une possibilité indéfinie de discours. [...] Ils ont rendu possible un certain nombre de différences. Ils ont ouvert l'espace pour autre chose qu'eux et qui pourtant appartient à ce qu'ils ont fondé. Dire que Freud a fondé la psychanalyse [...], c'est dire que Freud a rendu possibles un certain nombre de différences par rapport à ses textes, à ses concepts, à ses hypothèses qui relèvent toutes du discours psychanalytique lui-même.« 
Ritualized dialectic, expressed in the mechanisms of disputatio, was at the foundation of the schools' Western medieval education system and universities. However, was the Western university education system a unique model? It seems that irenic exchanges and structures of disputatio could have existed in the Islamic and Judaic worlds due to the fact that the tradition of Aristotle's dialectic is common to the main cultures of Eurasia, but not in the fashion of Western universities as a corporative association of education and the search for truth. Nor was this the case in the Byzantine world, where the educational system was closer to the classical school of antiquity than to the corporative medieval association of Western universities.

\section{Polemical Methods: The Dialectics of Debates and Polemics}

As stated in the introduction, there were two kinds of disputationes in the Middle Ages: an irenical one - the one described above as the scholastic disputatio - and a more argumentative one - the one linked with polemics and debates in the public sphere and the political scene of the exchanges.

\section{What is Polemics?}

The first question we could formulate while reading polemical treatises from the end of the Middle Ages could be: what should we understand when we speak of polemics? Of course, there is a distinction between polemics and controversy: polemics could be the controversy from which the learned and elitist field is derived, while controversy is spread within the broader public sphere. However, there could be another, or more thorough way to understand polemics. There could be what we call "apparent " polemics, those that are institutionalized.

Moreover, there could also be immersed polemics; that is to say, those that are not publicly displayed but those that are at the very heart of all debates. In the contextual example of the Great Schism, the real and true stakes of debates were not openly admitted.

The time of the Great Western Schism (1378-1417) was a highly polemic time because of the major crisis of the Church: two popes, sometimes three, were asserting claims to the Chair of Peter and no one knew who was the right one. The intensity of the production of treatises proved the need for explanations at the time. Polemics between the Avignonese obedience (the pope in Avignon) and the Roman obedience (the one in Rome) during the Great Western Schism were the central part of the treatises, but there were also theorizations about power, ecclesiological structures, the government of the Church and so forth, between royal counselors and curial counselors in the Parisian political scene, between legists and theologians in the universities, between canonists and civilists elsewhere. When we look closely at the debates, things are more complicated than simple debates on a straightforward topic. Behind the debates, indeed, were hidden other debates, deeper ones. Official polemics said something other than what could be seen on the surface. So, the historian has to take care to approach the debates not so much for their content - sometimes risking growing tired of this - as for the balance of power, for the stakes that they underlie and for the tensions that they reveal or that they engender. Often, the stake in the debates is less religious than it is social and political: it is not a point of content but a point of hierarchical positions. For the time of the Great Schism, the debates about the cephalic unity of the papacy and on the means of transfer reveal to the historian the other underlying realities: without the delegation of any central authority, the protagonists - often universities - create a monopoly in dictating public opinion with the intention of setting themselves up as natural councilors of power. By the academic debates, they claim to impose their program of reforms on the councils that were opened (Pisa, Roma, Constance). So, fronts take shape that transcend the 
political factions of the surface. More specifically, the historian's function is to trace the very complex ramifications of the debates. Those ramifications are supposed to bring to light the underlying structures and stakes of the debates, unseen at first sight and indirectly stated in the content of debates. The term "polemical regimes « refers to debates with intertextuality, polemics, front lines, and breakdowns. In a word, polemics produce doctrines.

Polemics as Events of History: The Case Study of the Great Western Schism (1378-1417) ${ }^{22}$

To envisage the history of this major crisis in the Church, the Great Schism, means to consider the debates as events of history, in the same way as men are themselves actors. ${ }^{23}$ First of all, the debates proved to be engines of discursive production: the debates built the doctrines. The meanings of the words were in accordance with the division of the memberships, and the words became identical signals of their respective positions. How can we express more clearly that the words are coded, then trapped, and that the debates become more explicit for the historian, only thanks to their slow and patient reconstruction, sector by sector, text by text, within a vast intertextual constellation, for a new history of the production of knowledge at the time of the Great Schism? Let us take one example: the discourse about the Good Shepherd. One of the main themes discussed in the polemical literature of the Great Schism was the figure of the good pope and the bad pope. Theorists and theologians associated the good pope with the Good Shepherd »that leads his sheep«, according to the Gospel of John. They associated the bad pope with the hireling (mercenarius), the antithetical figure of the Good Shepherd who »beholdeth the wolf coming and leaveth the sheep". The lousy pastor pretty soon became synonymous with the heretical pope. The confrontation between the two main camps was a confrontation by means of exegesis on the verse of John 10, 11: "I am the good shepherd. The good shepherd lays down his life for the sheep«. If the good shepherd had to lay down his life for the sheep, how much more should the good pope lay down his crown to solve the Schism? For the one side, if Benedict XIII, the pope of Avignon, could not follow the example of Christ by resigning his function, then he should be ipso facto deposed. On the contrary, those who argued in favor of the pope said that a resignation would mean an abandonment or desertion and that the pope should never resign: Nullo modo debet dominus Bonifacius verus pastor Ecclesie renunciare papatui. ${ }^{24}$ The period became oversaturated with this polemic. That is why, at the beginning of the fifteenth century, in 1408, when Jean Gerson, the famous French Parisian theologian, commented the verse Bonus pastor animam suam dat pro ovibus sui, in a sermon in front of the Archbishop of Reims, he intentionally deactivated and disarmed the polemicism of the current debates. He reinserted the exegesis in the longterm tradition of the biblical reading, refusing to carry on the polemical aspects of the theme. What is very important for our demonstration is the fact that a famous scholastic professor refused to allow the polemical disputatio to go further. Too much polemic kills polemic. 


\section{Between Oversaturation of Polemics and a Way out of the Scholastic Sphere: The Case of Jean Gerson}

Too much polemic kills polemic. When he wrote about polemics and polemicism, Jean Gerson warned about the excess of discussions, disputations, and debates. His awareness of the uselessness and worthlessness of the debates was something new in the academic scholastic field: Cessent quippe tali (discussiones)! Let us stop any kind of discussions! ${ }^{25}$ Jean Gerson refused the polemics because debates had been cut off from their ethic roots, the disputatio tradition. Violent debates produced a certain degree of lassitude and weariness. Debates and arguments only produced divisions! Pierre d'Ailly also said that polemics only produced discord and contention: ${ }^{26}$ indisposicio, vacillacio, precipitation, contencio et discordia. Scholastic intellectuals irritated when faced with the multiplicity of useless debates. They therefore questioned the whole scholastic system based on the disputationes as the leading intellectual tool to produce ideas, doctrines, and to seek the truth. This also challenged their belonging to the scholastic university. As Daniel Hobbins has recently shown, Jean Gerson had flown far away from the endless university debates to reach a non-academic audience in order to feel more useful in the public sphere of laypeople:

The full story of Gerson's success as a publicist. We can say with confidence that Gerson reached a public far different from that of earlier schoolmen. (...) The public for intellectuals was growing; it was a public that in turn advised, preached, wrote, and informed the rest of society; and more effectively than any previous schoolman, Gerson reached this public. ${ }^{27}$

Daniel Hobbins has, moreover, shown how important the shift of the figure of the intellectual was:

Perhaps the most interesting part of this story is Gerson's awareness of a shift in approach from earlier days. Something has changed: the university master now has a nonacademic public, not merely in preaching but also in writing; he has a responsibility to reach them and must adapt his message to them. (...) Now more than ever, the schoolman became a public figure. Hence my model: the schoolman as 'public intellectual'. (...) In an age when the commentary seemed downright backward-looking, he represents the coming of a new type, made possible by the shift to the tract: the theologian as a controversialist, concerned with issues of public morality, always ready to give his opinion on current popular topics and eager to reach a large audience. (...) Comparing him to our contemporary public experts, we may think of him as a medieval public intellectual, the licensed expert in moral theology. ${ }^{28}$

25 Jean Gerson, Tractatus de unitate Ecclesiae, 140 »Unitas Ecclesiae ad unum certum Christi vicarium videtur melius procuranda si neque ante concilium neque in concilio neque postmodum quaerantur fieri justificationes vel injustificationes eorum quae hinc inde facta sunt, ut de intrusione huius vel illius papatum, de processibus primo fulminatis in alterutros, de violatione juramentorum et votorum, de substractione vel neutralitate vel libertatis ecclesiarum particularium reductione, de impositione schismatum vel haeresum, de adhaesione reprobanda vel laudanda alterius partis obedientiae, de sententiis excommunicationum aut aliarum poenarum. Cessent quippe tali.«

26 Peter of Ailly, Capitula agendorum, 551, for the manuscript B (cf. Finke). See also Vaticano, Vat. lat. 395, 551: »Et istud multum expedire videtur quia in simplicibus magna oritur indisposicio atque in religione fidei nocet vacillacio, precipitatio, contencio et discordia in huiusmodi materiis inter litteratos atque scolasticos et famosos viros. Item propter periculum quandoque firme atque pertinacis adhesionis ad unam partem.«

27 Hobbins, Authorship and Publicity, 151.

28 Ibid., 129, 147. 
All in all, the dialectical and non-irenical methods of the debate help to unmask the institutional stakes with regard to power and the ambitions of the actors. Debates of opinion, indeed, studied from the historical angle, are as much the actors as the revelations of the underlying tensions, which are present across the highest political echelons of time: the Church, the University of Paris and the Royal Council, but also the Parliament, the Chapter of Notre-Dame, mendicant networks, the other French universities, etc. At that time, all those institutions were losing their monopoly on public opinion, access to which the University of Paris dreamt of controlling. By their rhetoric of control and their expertise, the Parisian academics already saw themselves sharing political decisions with the high authorities: on the one hand, they would consult alongside the royal council, like natural counselors; on the other hand, they were, next to the Petrine power itself, the authority of jurisdictional magistery, next to which they would look like doctrinal magistery - Saint Paul was, in a way, one guarantee for this unstated aim. Thus, it is better explained as being the time of the release of texts from their academic sphere and from their scholastic seclusion, the target being the public sphere; that is to say, control over public opinion. The Great Schism was the opportunity for the university and the world of knowledge to achieve a wider distribution of its production and to reconsider the world of laymen, even if it meant setting up new editorial strategies, as Daniel Hobbins showed well ${ }^{29}$. The moment of the Great Schism also offered the opportunity - albeit missed - to have a voice and seize power on the political scene, which, afterward, the academics would no longer have. The debates later stimulated ecclesiological, unpublished permissions that were previously unthinkable. Indeed, the time of the Great Schism was one that none of the ecclesiastic worlds would have thought possible. Never before had the experience of the subtraction of obedience been not merely conceivable but applied officially. Rarely had the thought of ecclesiological alternatives to the monarchic government of the pope been met with so much excitement. The ideas of the forces of opposition, proposals to limit papal power, and incentives to resist the full powers emerged everywhere. The time of the debates was also a time of hopes for change.

\section{Conclusion}

To sum up, commentaries, on the one hand, and polemical treatises, on the other hand - that is to say, roughly speaking, irenic disputationes and polemical disputationes - produce, by their mechanisms, ideas and doctrines, thought, and ecclesiological content. Undeniably, the intellectual practices (disputatio, debates, polemics) produce theories. We have to decode the practices to understand better the theoretical constructions. In humanist criticism and the criticism of the Enlightenment and Aufklärung in the Middle Ages, there was, fundamentally, a criticism of scholasticism. However, what was being attacked? Did they attack the intellectual relation to the auctoritas seen as a constraint for the mind and ideas or, to put it another way, freedom and autonomy? Did the critics not understand how autonomy was embedded deep in the art of the scholastic construction of commentaries? Theories of modernization or secularization, meaning to sweep away the past, are contradicted and denied through practices themselves: scholasticism, indeed so-called "second scholasticism ", continued widely in the practices employed at least until the seventeenth and eighteenth centuries.

29 Hobbins, Authorship and Publicity, esp. ch. 5: »The Schoolman as Public Intellectual«, 128151. 


\section{References}

\section{Primary Sources}

Aristoteles Latinus, Ethica Nicomachea XXVI, 1-3. Fasc. 3: Translatio Roberti Grosseteste Lincolniensis sive "Liber Ethicorum «. A. Recensio Pura 50.8 (Leiden, 1974).

Johannes Buridanus, Quaestiones super decem libros Ethicorum (Frankfurt, 1968) fol. 168ra-202rb. Johannes Versoris, Quaestiones super libros ethicorum Aristotelis (Cologne, 1494).

Jean Gerson, Tractatus de unitate Ecclesiae, ed. P. Glorieux 6, § 272, 136145.

Peter of Ailly, Capitula agendorum (February 1412), ed. Finke 4, 548583.

Thomas Aquinas, Commentary on the Metaphysics of Aristotle, trad. J. P. Roan, 2 t. (Chicago, 1964). Thomas Aquinas, Sententia libri Ethicorum, ed. Léonine 47/2 (Rome, 1969) 442-549.

\section{Secondary Sources}

Angelelli, Ignacio, The technics of disputation in the history of logic, Journal of Philosophy 67 (1970) 800-815.

Bazàn, Bernardo C., La quaestio disputata, in: Robert Bultot (eds.), Les genres littéraires dans les sources théologiques et philosophiques médiévales: Définition, critique, exploitation. Actes du colloque international de Louvain-la-Neuve (Louvain-la-Neuve, 1982) 31-49.

Bazàn, Bernardo C., Gérard Fransen, John Wippel and Danielle Jacquart (eds.), Les Questions disputées et les Questions quodlibétiques dans les Facultés de théologie, de droit et de médecine (Turnhout, 1985).

Bourdieu, Pierre, Le champ scientifique, Actes de la recherche en sciences sociales 2-3 (1976) 88-104.

Bourdieu, Pierre, Leçon sur la leçon (Paris, 1982).

Bourdieu, Pierre, Méditations pascaliennes (Paris, 2007).

Bourdieu, Pierre, Sciences de la science et réflexivité (Paris, 2001).

Chenu, Marie-Dominique, Introduction à l'étude de saint Thomas d'Aquin (Montréal-Paris, 1954).

De Libera, Alain, Pierre Abélard, in: Claude Gauvard, Alain De Libera and Michel Zink (eds.), Dictionnaire du Moyen Âge (Paris, 2000) 1097-1101.

De Libera, Alain and Irène Rosier (ed.), Argumentation in the Middle Ages, in: Argumentation 1/4 (1987) 355-457.

Foucault, Michel, Qu'est-ce qu'un auteur? in: Michel Foucault, Dits et écrits 1, 1954-1975 (Paris, 2001) 817-849.

Gindhart, Marion and Ursula Hundert (eds.), Disputatio 1200-180o: Form, Funktion und Wirkung eines Leitmediums universitäter Wissenskultur (Berlin, 2010).

Habermas, Jürgen, Strukturwandel der Öffentlichkeit: Untersuchungen zu einer Kategorie der bürgerlichen Gesselschaft (Berlin, 1962).

Habermas, Jürgen, Theorie des kommunikativen Handelns (Frankfurt, 1985).

Hobbins, Daniel, Authorship and Publicity before Print: Jean Gerson and the Transformation of Late Medieval Learning (Philadelphia, 2009).

König-Pralong, Catherine, Avènement de l'aristotélisme en terre chrétienne. L'essence et la matière: Entre Thomas d'Aquin et Guillaume d'Ockham (Paris, 2005).

Maierù, Alfonso, Academic exercises in Italian universities, in: Alfonso Maierù (ed.), University Training in Medieval Europe (Leiden, 1994).

Mandonnet, Pierre, Saint Thomas d'Aquin créateur de la dispute quodlibétique, Revue des Sciences philosophiques et théologiques, 15/4 (1926) 477-506. 
Marmursztejn, Elsa, L'Autorité des maîtres: Scolastique, normes et société au XIIIe siècle (Paris, 2007).

Meuthen, Erich, Kölner Universitätsgeschichte, Herausgegeben von der Senatskommission für die Geschichte der Universität zu Köln 1: Die alte Universität (Cologne, 1988).

Périgot, Béatrice, Dialectique et littérature: Les avatars de la dispute entre Moyen Âge et Renaissance (Paris, 2005).

Périgot, Béatrice, Antécédences: De la disputatio médiévale au débat humaniste, Memini 11 (2007) 43-61.

Sère, Bénédicte, Les débats d'idées à l'époque du Grand Schisme: Ecclésiologie et politique (Turnhout, 2016).

Sère, Bénédicte, La disputatio dans l'université médiévale: Esquisse d'un usage public du raisonnement?, in: Patrick Boucheron and Nicolas Offenstadt (eds.), L'espace public au Moyen Âge: Débats autour de Jürgen Habermas (Paris, 2011) 251-275.

Sère, Bénédicte, Penser l'amitié au Moyen Âge: Étude historique des commentaires sur les livres VIII et IX de l'Éthique à Nicomaque, (XIIIe-XVe siècle) (Turnhout, 2007).

Sère, Bénédicte (ed.), Les régimes de polémicité au Moyen Âge (Rennes, 2019).

Sère, Bénédicte, Thomas d'Aquin contre Siger de Brabant, 1270: Chronique d'une dispute, in: Patrick Boucheron and Vincent Azoulay (eds.), Le mot qui tue: Une histoire des violences intellectuelles de l'Antiquité à nos jours (Seyssel, 2009) 99-115.

Vignaux, Paul, La Philosophie au Moyen Âge (ed. Ruedi Imbach) (Paris, 2004).

Waquet, Françoise, La longue vie de la dispute: Contribution à l'histoire d'un genre universitaire, in: Marc Fumaroli, Christian Mouchel and Colette Nativel (eds.), République des lettres, république des arts: Mélanges offerts à Marc Fumaroli (Geneva, 2008) 135-147.

Weijers, Olga, La "Disputatio« à la Faculté des arts de Paris (1200-1350 environ) (Turnhout, 1995).

Weijers, Olga, De la joute dialectique à la dispute scolastique, Académie des Inscriptions et Belles-Lettres, 143/2 (1999) 508-518.

Weijers, Olga, La "Disputatio" dans les Facultés des arts au Moyen Âge (Turnhout, 2002).

Weijers, Olga, A Scholar's Paradise Teaching and Debating in Medieval Paris (Turnhout, 2015).

Weijers, Olga, Quelques observations sur les divers emplois du terme disputatio. In: José Francisco Meirinhos (ed.), Itinéraires de la raison: Études de philosophie médiévale offertes à Maria Cândida Pacheco (Louvain-la-Neuve, 2005) 35-48. 